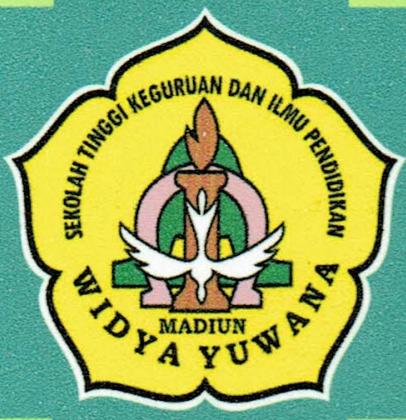

Vol, 7, Tahun ke.4, April 2012

ISSN; 2085-0743

REMAJA: SUMBER DAYA INSANI MENYONGSONG KEMANDIRIAN BANGSA INDONESIA JS. Wibowo Singgih

REMAJA DAN PENGHAYATAN EKARISTI: SUATU HABITUS

BARU

Ola Rongan Wilhelmus

REMAJA KATOLIK, GEREJA, DAN EKARISTI Agustinus Supriyadi

PERAYAAN EKARISTI HARI MINGGU DI PAROKI DAN PERKEMBANGAN HIDUP ROHANI KAUM REMAJA: SEBUAH PELUANG Don Bosco Karnan Ardijanto

STRATEGI MENJADIKAN REMAJA MUSIM SEMI BAGI MASYARAKAT, BANGSA DAN GEREJA Antonius Tse

PROBLEM DAN ABORSI DITINJAU DARI MORAL KATOLIK SERTA USAHA MEMAKNAI LITURGI UNTUK MENGURANGI

PRAKTEK ABORSI DI TENGAH REMAJA KATOLIK Antonius Virdei Eresto Gaudiawan

PROBLEM REMAJA DAN PENILAIAN MORAL KATOLIK TENTANG SEX DI LUAR NIKAH Suparto

DOSA DAN RAHMAT SEKRAMEN PENGAKUAN DOSA BAGI REMAJA Robertus Joko Sulistyo

ANIMASI PERAYAAN TOBAT YANG TEPAT BAGI REMAJA Aloysius Suhardi

REMAJA DAN MASA DEPANNYA: SEBUAH UPAYA PASTORAL BAGI REMAJA Albert I Ketut Deni Wijaya

BELAJAR SEBAGAI AKTIVITAS REMAJA MEMPERSIAPKAN MASA DEPAN Agustinus Wisnu Dewantara

Lembaga Penelitian

Sekolah Tinggi Keguruan dan Ilmu Pendidikan "Widya Yuwana" MADIUN 


\section{JPAK JURNAL PENDIDIKAN AGAMA KATOLIK}

Jurnal Pendidikan Agama Katolik (JPAK) adalah media komunikasi ilmiah yang dimaksudkan untuk mewadahi hasil penelitian, hasil studi, atau kajian ilmiah yang berkaitan dengan Pendidikan Agama Katolik sebagai salah satu bentuk sumbangan STKIP Widya Yuwana Madiun bagi pengembangan Pendidikan Agama Katolik pada umumnya.

\section{Penasihat}

Ketua Yayasan Widya Yuwana Madiun

Pelindung

Ketua STKIP Widya Yuwana Madiun

Penyelenggara

Lembaga Penelitian STKIP Widya Yuwana Madiun

Ketua Penyunting

Hipolitus Kristoforus Kewuel

\section{Penyunting Pelaksana}

FX. Hardi Aswinarno

DB. Karnan Ardijanto

\section{Penyunting Ahli}

John Tondowidjojo

Ola Rongan Wilhelmus

Armada Riyanto

Sekretaris

Gabriel Sunyoto

\section{Alamat Redaksi \\ STKIP Widya Yuwana}

Jln. Mayjend Panjaitan. Tromolpos: 13. Telp. 0351-463208. Fax. 0351-483554

Madiun 63137 - Jawa Timur - Indonesia

Jurnal Pendidikan Agama Katolik (JPAK) diterbitkan oleh Lembaga Penelitian, STKIP Widya Yuwana Madiun. Terbit 2 kali setahun (April dan Oktober). 


\section{JPAK}

Vol. 7, Tahun ke-4, April 2012

ISSN; 2085-0743

\section{DAFTAR ISI}

03 Editorial

05 REMAJA: SUMBER DAYA INSANI MENYONGSONG KEMANDIRIANQBANGSAINDONESIA JS Wibowo Singgih

14 REMAJA DAN PENGHAYATAN EKARISTI: SUATU HABITUS BARU Ola Rongan Wilhelmus

26 REMAJA KATOLIK, GEREJADAN EKARISTI Agustinus Supriyadi

43 PERAYAAN EKARISTI HARI MINGGU DI PAROKI DAN PERKEMBANGAN HIDUP ROHANI KAUM REMAJA: SEBUAH PELUANG

Don Bosco KarnanArdijanto

58 STRATEGI MENJADIKAN REMAJA MUSIM SEMI BAGI MASYARAKAT, BANGSADAN GEREJA Antonius Tse

75 PROBLEM REMAJA DAN ABORSI DITINJAU DARI SEGI MORAL KATOLIK SERTA USAHA MEMAKNAI LITURGI UNTUK MENGURANGI PRAKTEK ABORSI DI TENGAHN REMAJAKATOLIK Antonius Virdei Eresto Gaudiawan

102 PROBLEM REMAJA DAN PENILAIAN MORAL KATOLIK TENTANG SEX DI LUAR NIKAH Suparto

119 DOSA DAN RAHMAT SAKRAMEN PENGAKUAN DOSA BAGI REMAJA Robertus Joko Sulistyo 


\section{ANIMASI PERAYAAN TOBAT YANG TEPAT BAGI}

REMAJA

Aloysius Suhardi

142 REMAJA DAN MASA DEPANNYA: SEBUAH UPAYA PASTORALBAGI REMAJA Albert I Ketut Deni Wijaya

155 BELAJAR SEBAGAI AKTIVITAS REMAJA MEMPERSIAPKAN MASA DEPAN

Agustinus Wisnu Dewantara 


\title{
PERAYAAN EKARISTI HARI MINGGU DI PAROKI DAN PERKEMBANGAN HIDUP ROHANI KAUM REMAJA: SEBUAH PELUANG ${ }^{1}$
}

\author{
Don Bosco Karnan Ardijanto \\ Sekolah Tinggi Keguruan dan Ilmu Pendidikan Agama Katolik \\ (STKIP) Widya Yuwana Madiun
}

\begin{abstract}
Abstrak
Perayaan Ekaristi hari Minggu di paroki sering dipandang sebagai kegiatan yang bersifat rutinitas belaka. Maka Perayaan Ekaristi masih kurang mendapatkan perhatian yang seharusnya. Namun fakta menunjukkan bahwa umat masih tetap datang dan berkumpul menghadiri Perayaan Ekaristi hari Minggu. Ini membuktikan bahwa Perayaan Ekaristi hari Minggu masih mendapat tempat yang istimewa di hati umat beriman, termasuk remaja. Untuk itu para petugas pastoral, khususnya para imam, hendaknya memanfaatkan dengan baik berbagai peluang perayaan Ekaristi hari Minggu untuk membantu mengembangkan hidup rohani umat maupun hidup rohani remaja. Melakukan persiapan yang serius, mengembangkan kreatifitas, serta memanfaatkan berbagai kemungkinan penyesuaian yang dapat dilakukan dalam perayaan Ekaristi membantu terwujudnya pengembangan hidup rohani umat, terutama hidup rohani remaja.
\end{abstract}

Key Words :Perayaan Ekaristi Hari Minggu, Keterlibatan Remaja, Perkembangan Hidup Rohani Remaja.

\section{Pendahuluan}

Mengamati keterlibatan umat beriman, termasuk juga para remaja, dalam Perayaan Ekaristi hari Minggu di paroki-paroki, ada hal yang menggembirakan (Roguet, 1984: 5). Mereka terlihat begitu

1 Karya Ilmiah berjudul "Perayaan Ekaristi Hari Minggu di Paroki dan Perkembangan Hidup Rohani Kaum Remaja: Sebuah Peluang" dipresentasikan dalam Seminar Sehari bertemakan "Remaja dan Liturgi" yang diselenggarakan oleh Lembaga Penelitian STKIP Widya Yuwana, Madiun bekerjasama dengan Wina Press, Madiun pada hari Kamis, 15 Desember 2011 bertempat di Auditorium STKIP Widya Yuwana, Madiun. 
antusias dan sukacita dalam mengikuti Perayaan Ekaristi hari Minggu dengan ikut menyanyi, duduk tenang mendengarkan Sabda Allah, khusuk berdoa, dan sebagainya. Ada juga yang mengambil peran khusus dalam Perayaan Ekaristi itu sebagai putra-putri altar, organis, solis, kolektan, ataupun tugas lainnya.

Di lain pihak, tampak juga remaja-remaja yang dalam Perayaan Ekaristi lebih sering berbicara atau ngobrol dengan temannya, tidak berperan serta aktif dan kurang bergairah. Ada juga yang malahan duduk-duduk dan ngobrol di luar gedung Gereja di mana perayaan Ekaristi dilaksanakan. Ada sebagian juga datang terlambat dan setelah Komuni pulang lebih awal atau menerima Komuni secara asal-asalan karena sudah rutin dan biasa.

Akar masalah kurangnya keterlibatan remaja dalam Perayaan Ekaristi ini adalah "motivasi wajib" (Ekristi dilihat sekedar sebagai suatu kewajiban) yang menyebabkan mereka merasa terpaksa hadir dalam Perayaan Ekaristi hari Minggu (Mayor, 1999:2), selain karena rendahnya pemahaman umat beriman, termasuk para remaja akan hakekat Perayaan Ekaristi dan makna Kurban Misa sehingga mereka merasa tidak tertarik untuk berpartisipasi karena tidak mengerti (Mayor, 1999:2; Roguet, 1984:5).

Tidak jarang justru orangtualah yang menanamkan "motivasi wajib" kepada anak-anak mereka untuk mengikuti perayaan Ekaristi hari Minggu. Pada hal sebagai pribadi yang sedang mencari dan berusaha menemukan identitas dirinya sendiri, para remaja tidak jarang melihat paksaan dari orangtua sebagai sesuatu yang tidak mereka inginkan: "Tentu saja kami ingin bebas, lepas, dan tidak ingin dijadikan produk orangtua untuk terus menerus menuruti apa yang mereka kehendaki dari kami ...." (Tangdilintin, 2008:31).

Selain itu, tidak jarang "motivasi wajib" juga diteguhkan oleh para guru agama di sekolah-sekolah yang meminta para siswa untuk mendapatkan tandatangan dari imam pemimpin Perayaan Ekaristi. Keterpaksaan semacam ini kerapkali juga menyebabkan para remaja mengikuti perayaan Ekaristi hari Minggu secara asal-asalan saja (entah ngobrol atau duduk di luar, kadang-kadang keluar, dan sejenisnya), pokoknya ikut, hadir, dan mendapatkan tandatangan pastor demi nilai mata pelajaran agama Katolik.

Bertolak dari situasi di atas dapatlah diajukan berbagai permasalahan: bagaimanakah perayaan Ekaristi hari Minggu yang juga dihadiri para remaja dapat membantu mereka bertumbuh dalam kehidupan rohani? Adakah pandangan tentang tahap-tahap 
perkembangan rohani remaja? Dengan kata lain, sejauh mana dapat ditemukan berbagai kemungkinan atau peluang untuk mengeksplorasi Perayaan Ekaristi hari Minggu sehingga membantu para remaja mengembangkan kehidupan rohani mereka?

\section{Tiga Tahap Perkembangan Hidup Rohani Remaja}

Perkembangan hidup rohani remaja yang disajikan di sini didasarkan pada tulisan Joseph Moore (1988) berjudul "Adolescent Spiritual Development: Stages and Strategies". Menurut Moore (1988), ada 3 (tiga) tahap perkembangan dalam hidup rohani kaum remaja, yakni: tahap pemurnian, tahap pencerahan, dan tahap persatuan.

Pertama adalah tahap pemurnian. Pemurnian dalam arti rohani berarti pemurnian dari dosa-dosa karena kegagalan seseorang mengembangkan jati diri yang sejati sebagai anak-anak Allah. Dalam arti psikologis, pemurnian berarti menanggalkan topeng-topeng yang menyebabkan seseorang tidak mampu menjadi pribadi yang otentik. Oleh karena itu, tahap pemurnian merupakan suatu proses pemurnian dari gambaran diri yang keliru, khususnya dari rasa rendah diri, menjadi pribadi yang memiliki gambaran diri yang sejati.

Kaum remaja yang merindukan relasi yang lebih mendalam dengan Allah, harus mengawalinya dengan membangun konsep atau gambaran diri yang sehat dan tepat. Dengan kata lain, mengembangkan cinta diri yang sehat dan menghargai keunikan diri pribadi, yakni percaya bahwa dirinya sudah dicintai Allah (Yoh 15:12) merupakan langkah awal untuk mencintai Allah dan sesama.

Kesadaran bahwa dirinya dicintai merupakan salah satu akar persoalan kaum muda saat ini. Rasa rendah diri adalah dasar dari begitu banyak persoalan kaum remaja, termasuk persoalan hidup rohani. Jika seseorang merasa tidak dicintai dan tidak layak/pantas, ia juga akan merasa bahwa Allah tidak peduli terhadap dirinya dan pasti tidak akan menjawab doa-doanya.

Kedua, tahap pemurnian. Pada tahap pemurnian ini, remaja sangat membutuhkan pengembangan relasi inter-personal, dan Allah dapat dialami sebagai teman. Harga diri dikembangkan dengan membangun relasi inter-personal di dunia ini. Bimbingan rohani dimulai dengan menekankan persahabatan Yesus dan perhatianNya kepada setiap orang atau setiap pribadi (Mat 6: 5-34, 7:7-11, 11: 2830, 12: 46-50; Luk 10:38-42, 15: 11-32; Yoh 11:1-44, 14:1-31, 15:117). Selain itu, pemenuhan kebutuhan kaum remaja untuk dicintai, 
dihargai, dan diterima dapat juga diwujudkan dengan menjadi bagian atau anggota dari suatu komunitas, sedangkan peran penting para pendamping kaum remaja lebih terletak pada pelayanan persahabatan dan sebagai "bidan". Artinya tugas mereka terpusat upaya membangun dan mengembangkan relasi dengan kaum remaja, meneguhkan kekayaan dan nilai yang terdapat dalam diri kaum remaja serta memilih strategi-strategi yang mampu mengembangkan suatu komunitas yang mendukung dan menumbuhkan suatu gambaran diri yang positif dalam diri kaum remaja. Dengan demikian remaja dapat melihat dan menemukan nilai-nilai dan panggilan hidup mereka sendiri.

Tahap kedua disebut sebagai tahap pencerahan atau penerangan. Di dalam terang, seseorang dapat melihat segala sesuatu dengan jelas dan asli. Dalam konteks perkembangan pribadi seseorang, apabila seseorang menanggalkan pembelaan dirinya atau rasa rendah dirinya, maka ia dapat mulai mengenali dirinya seadanya sebagaimana Allah melihatnya. Dengan kata lain, apabila seseorang mampu mengenali dirinya sebagai pribadi yang dapat dicintai karena ia dicintai dengan kasih abadi dari Allah, maka ia dapat mulai berpusat pada dirinya dan mulai melihat kepada Yesus. Selanjutnya dia akan mampu mengembangkan suatu relasi yang matang dengan Allah. Oleh karena itu, seorang remaja pertama-tama harus menerima dirinya sendiri sebagaimana adanya sebelum relasinya dengan Yesus dapat berkembang.

Setelah mengembangkan identitas diri yang positif, maka para remaja akan menemukan dan memiliki daya dari dalam dirinya untuk berani keluar dari kelompoknya dan berjalan sendiri "mendaki bukit." Selain kehadiran Yesus di tengah-tengah kelompok, para pendamping juga perlu mempertemukan Yesus secara pribadi dengan para remaja sehingga relasi dapat berkembang, dan kemudian mereka merasakan kebutuhan untuk berkomitmen. Tahap ini merupakan saat dimana hidup rohani mulai tertanam di dalam hati. Pada titik ini peranan pendamping kaum remaja lebih sebagai agen yang mengundang kaum muda untuk mengembangkan dan memiliki iman yang mandiri: membangun dan menghidupi suatu relasi dengan Yesus dan berkomitmen kepadaNya.

Tahap ketiga merupakan tahap persatuan. Pada tahap ini seseorang mengalami dirinya sebagai pribadi yang utuh yaitu pribadi yang mengalami persatuan dengan Allah yang hidup dan sekaligus persatuan dengan seluruh ciptaan. Persatuan ini memiliki perspektif 
yang berkelanjutan. Untuk memasuki tahap rohani ini diperlukan sikap menyerahkan diri kepadaAllah.

Ciri tahap persatuan ini adalah bahwa seseorang memiliki iman reflektif dan bertumbuh menjadi pribadi yang reflektif pula. Ia mulai bertumbuh dan tanggungjawab terhadap rencana, niat, keputusan, gaya-hidup, dan keyakinan-keyakinannya sendiri. Tahap ini juga ditandai dengan pandangan terhadap dunia secara lebih luas. Kaum remaja mampu bertumbuh dalam empati dan bela rasa yang mendorong mereka untuk membantu orang lain. Mereka juga menyadari bakat pribadinya dan siap membagikan talentanya bagi keuntungan orang lain.

\section{Perayaan Ekaristi: Memurnikan, Menerangi, dan Mem- persatukan}

Perayaan Ekaristi merupakan sumber dan puncak kehidupan Gereja dan seluruh hidup kristiani (SC 10) sehingga dapat dikatakan bahwa di dalam Ekaristi kudus terdapat seluruh kekayaan rohani Gereja. Memang, Misa kudus dan Komuni kudus merupakan hal yang tak terpisahkan dari kehidupan kristiani. Namun persoalannya adalah: apakah Misa dan Komuni kudus akan berbuah bagi kehidupan kristiani atau tidak, sangatlah bergantung pada bagaimana umat beriman mempersiapkan diri dan mengambil bagian di dalamnya. Disposisi peserta sangat penting dan ikut menentukan buah-buah dan daya kuasa Ekaristi dalam hidup kaum beriman (Vazhakala, 2005). Ibu Teresa juga sangat menekankan pentingnya disposisi dan motivasi diri dalam mengikuti perayaan Ekaristi dengan mengingatkan para imam agar merayakan setiap perayaan Ekaristi dengan penuh kesetiaan, kesegaran, penghayatan, dan semangat: "Para imam Allah, rayakanlah Misa ini seolah-olah ini merupakan misa perdanamu, Misa terakhirmu, dan satu-satunya Misamu" (Vazhakala, 2005).

Dari kacamata perkembangan hidup rohani (Mazzella), maka dapat dikatakan bahwa perayaan Ekaristi memiliki 3 (tiga) tahap: tahap pemurnian, tahap pencerahan, dan tahap persatuan (Vazhakala, 2005). Di dalam Ritus Pembuka terdapat ritus pertobatan dimana seluruh peserta perayaan Ekaristi diajak untuk mengakui semua dosa kesalahannya dan memohon ampun kepada Allah atas segala dosa kesalahannya. Kemudian peserta menerima absolusi dan diakhiri dengan seruan Tuhan Kasihanilah. Ritus pertobatan ini dapat disebut sebagai tahap pemurnian sekaligus awal dari perkembangan hidup 
rohani. Proses pemurnian ini sangat bergantung pada usaha, ketulusan hati, kehendak baik dan terutama kerjasama seseorang dengan rahmat Allah. Bahkan tahap ini bisa jadi merupakan proses yang menyakitkan, karena menuntut pengorbanan diri untuk menerima kehendak Allah. Selain untuk menerima diri apa adanya, mengalami kasih dan pengampunan Allah dan mensyukuri kebaikan Allah ini, tahap pemurnian juga bertujuan menyiapkan dan mengarahkan peserta untuk mendengarkan Sabda Allah serta bersatu dengan Kristus dalam Sakramen Ekaristi secara pantas. Proses pemurnian ini selalu diulang dan dibaharui setiap kali perayaan Ekaristi dirayakan.

Sebagai bagian dari perayaan Ekaristi, tahap pencerahan disebut juga sebagai Liturgi Sabda. Tidak ada seorang penabur pun akan menaburkan benih, jika tanah tidak dipersiapkan dengan seksama, karena dia tahu bahwa benih-benih akan tumbuh subur dan menghasilkan buah kalau ditaburkan di tanah yang dibajak, dibersihkan, dan dipupuk. Hal yang sama juga berlaku bagi setiap peserta Perayaan Ekaristi yang harus mengolah batinnya sedemikian rupa agar menjadi lahan subur untuk menerima benih Sabda Allah yang ditaburkan ke dalam hatinya saat menghadiri Perayaan Ekristi.

Liturgi Sabda merupakan salah satu bagian utama dari perayaan Ekaristi sekaligus juga merupakan bagian integral dari perkembangan hidup rohani. Oleh karena itu, para peserta Ekaristi Kudus perlu mempersiapkan diri dan mengarahkan perhatian dengan baik untuk mendengarkan Sabda Allah: "'Berbicaralah, sebab hamba-Mu ini mendengar" (1 Sam 3:10b), artinya baik imam yang menyampaikan homili maupun para peserta Perayaan Ekaristi hendaknya membaca teks Kitab Suci, merefleksikan, bermeditasi dan berkontemplasi dari Sabda Allah yang dibacakan dalam Perayaan Ekaristi. Melalui persiapan semacam ini peserta dapat mengalami bahwa Sabda Allah yang dibaca dan direnungkan dapat menyegarkan, meneguhkan, menguatkan, menghibur, menyemangati, menuntun, membimbing, mengarahkan, mendorong, sekaligus menegur, mengkritik dan "menampar" mereka sehingga mereka berusaha dan berjuang untuk hidup seturut kehendak Allah. Dengan demikian pembacaan Sabda Allah dan homili mampu menumbuhkan benih-benih iman dalam diri para pendengar, menerangi hati dan budi mereka, mendorong serta menguatkan mereka supaya hidup seturut Sabda Allah, sekaligus mempersiapkan mereka untuk merayakan bagian Misa yang paling penting yaitu 


\section{Liturgi Ekaristi dan Komuni Kudus.}

Jika tahap pencerahan atau Liturgi Sabda diakhiri dengan Aku Percaya dan Doa Umat, maka Liturgi Ekaristi memuncak dalam Komuni Kudus. Bagian ini dapat disebut sebagai tahap Persatuan. Sebagaimana dalam kehidupan rohani, seseorang harus melewati lebih dahulu tahap pemurnian dan pencerahan untuk sampai pada tahap persatuan mistik, demikian pula dalam setiap perayaan Ekaristi ketiga tahap ini selalu dikenangkan, dibaharui, dan dihidupkan kembali.

Tahap persatuan ini mengajak peserta Perayaan Ekaristi untuk mempersatukan diri dan hidup mereka dengan Yesus Ekaristis. Diawali dengan persiapan persembahan, peserta diundang untuk mempersatukan seluruh peristiwa hidup mereka (syukur dan pujian atas segala kasih dan anugerah Allah, pengampunan Allah dalam hidup mereka, permohonan dan harapan hati mereka, segala rasa kekecewaan dan kegelisahan) dengan kurban Kristus sendiri. Persatuan ini dilanjutkan dengan persembahan diri Gereja yang dihaturkan dalam Doa Kristus Sang Imam Agung, yakni dalam Doa Syukur Agung. Persatuan dengan Kristus dan GerejaNya mencapai puncaknya dalam Komuni Kudus yang diimani sebagai puncak persatuan dengan Kristus dan GerejaNya, serta puncak partisipasi peserta dalam Ekaristi.

Persatuan dengan Kristus dan GerejaNya dalam Ekaristi Kudus mencurahkan dan mengalirkan daya kuasa Kristus dalam diri peserta untuk menghayati dan mengamalkan perutusan Gereja sendiri: melanjutkan karya-karya kasih Kristus bagi umat manusia di tengah-tengah masyarakat. Persatuan dengan Kristus dalam Komuni Kudus menumbuhkan kepedulian dan solidaritas terhadap sesama yang membutuhkan serta menggerakkan mereka untuk membagikan talenta-talenta dan anugerah-anugerah yang telah diterima demi kepentingan dan keuntungan sesamanya. Persatuan dengan Kristus dalam Komuni Kudus juga merupakan daya kekuatan untuk melayani Kristus dalam diri sesama yang miskin dan menderita:

"One thing I request of you, Your Grace, is to give us all the spiritual help we need. If we hear our Lord in the midst of us, with daily Mass and Holy Communion, I fear nothing for the Sisters nor myself; he will look after us. But without him I cannot be -I am helpless" (Vazhakala, 2005). 


\section{Perayaan Ekaristi Hari Minggu di Paroki: Peluang untuk Mengembangkan Hidup Rohani Para Remaja.}

Perayaan Ekaristi hari Minggu di paroki dimaksudkan bagi seluruh umat beriman dari berbagai usia (tidak terbatas pada para remaja saja) dan latar belakang sekaligus merupakan peristiwa atau kegiatan yang rutin terjadi. Karena alasan rutin itulah, maka Perayaan Ekaristi tidak jarang kurang mendapatkan perhatian yang seharusnya. Para petugas liturgi, tak terkecuali imam, bisa saja kurang mempersiapkannya dengan baik karena rutin dan sudah biasa. Demikian pula tidak jarang umat beriman datang menghadiri Perayaan Ekaristi dengan berbagai alasan yang tidak selalu tepat. Tidak jarang mereka pun berkomentar bahwa Perayaan Ekaristi hari Minggu itu sudah biasa dan tidak ada yang istimewa. Lepas dari berbagai alasan dan motivasi umat beriman, ada satu fakta yang tidak terbantahkan, yakni mereka tetap datang dan berkumpul menghadiri Perayaan Ekaristi hari Minggu. Dengan kata lain, Perayaan Ekaristi hari Minggu merupakan tempat dan saat umat beriman, termasuk juga kaum remaja, berkumpul bersama secara periodik dan teratur. Karena alasan inilah maka dicoba untuk menemukan berbagai peluang menggunakan kesempatan perayaan Ekaristi hari Minggu untuk membantu mengembangkan hidup rohani para remaja.

Para remaja sedang berjuang untuk menumbuhkan dan mengembangkan jati diri yang sejati sebagai anak-anak Allah, menjadi pribadi yang otentik dengan menanggalkan topeng-topeng kemunafikan; melawan rasa rendah diri; membangun konsep diri dan cinta diri yang sehat; menghargai keunikan dirinya percaya bahwa dirinya dicintai, dihargai dan diterima oleh Allah dan komunitasnya sendiri, membangun dan mengembangkan relasi interpersonal/persahabatan dengan teman sebaya dan Allah sendiri.

Ritus pertobatan dalam Perayaan Ekaristi hendaknya juga digunakan pemimpin perayaan untuk membantu para remaja memurnikan diri dari dosa-dosa kegagalan untuk menanggalkan topeng-topeng kepalsuan diri, kegagalan untuk yakin bahwa dirinya unik dan layak untuk diterima-dihargai-dicintai Allah dan temantemannya. Berbagai pertanyaan reflektif yang berkaitan dengan situasi hidup remaja dapat disusun dan dipadukan dalam cara tobat $\mathrm{C}$ sehingga akan sangat membantu para remaja memeriksa diri dan memurnikan diri dengan pertobatan. Sebuah contoh:

Tuhan Yesus Kristus, di dalam pembaptisan suci

Engkau telah memanggil kami untuk menjadi anak- 
anak Allah. Tuhan kasihanilah kami (2x).

Tuhan Yesus Kristus, kami kurang bisa bersyukur atas anugerah-anugerahmu dalam diri kami sehingga kami mudah iri hati dan tidak menerima diri kami. Kristus kasihanilah kami (2x).

Tuhan Yesus Kristus, kami kurang bisa mengakui kelemahan dan kesalahan kami sehingga kami menutupinya dengan berbagai bentuk topeng-topeng diri. Tuhan kasihanilah kami (2x).

Berbagai peran dalam Perayaan Ekaristi hari Minggu umumnya didominasi oleh orang-orang dewasa. Hal ini merupakan tantangan bagi setiap paroki untuk mengakomodasi dan membantu para remaja sebagai bagian dari Komunitas Ekaristi untuk memberikan sumbangan penting bagi jemaat. Sumbangan yang diberikan kepada komunitas ini membuat remaja merasa dirinya diterima, dihargai dan dicintai oleh komunitas umat beriman. Dengan kata lain, tugas-tugas tertentu yang dilakukan remaja dalam Komunitas Ekaristi memungkinkan para remaja mengaktualisasikan diri mereka, menambah kepercayaan diri, dan menjawabi kerinduan mereka untuk mengembangkan relasi inter-personal dengan temanteman mereka dan Allah. Oleh karena itu, pembinaan dan pendampingan kelompok misdinar, paduan suara remaja, kelompok kolektan, kelompok doa, atau kelompok remaja lainnya menjadi sangat penting. Berbagai jenis kelompok remaja yang didampingi dengan baik, teratur, dan serius akan membantu proses pemurnian diri remaja: membangun jati diri yang sehat dan sejati sebagai anak-anak Allah yang unik dan dicintai Allah.

Tahap pemurnian dan ritus tobat dalam Perayaan Ekaristi diharapkan dapat membantu para remaja menanggalkan rasa rendah dirinya, mengenali dirinya sebagaimana adanya, yakni pribadi yang dicintai Allah dan sesamanya, dan mengembangkan identitas diri yang positif sehingga mereka dapat mulai mengembangkan relasi yang matang dengan sesama dan Tuhan sendiri. Selanjutnya para remaja juga akan memiliki keberanian dari dalam diri untuk keluar dari kelompoknya dan mengalami perjumpaan pribadi dengan Yesus dan membangun komitmen mereka terhadap Yesus.

Liturgi Sabda sebagai bagian utama perayaan Ekaristi memiliki arti dan peranan istimewa dalam memberikan pencerahan bagi para remaja. Sabda yang diwartakan dan dijelaskan dengan baik dalam homili dapat meneguhkan identitas diri yang positif, menyapa 
dan menghantar para remaja kepada perjumpaan pribadi dengan Yesus, Sang Sabda, dan menantang mereka untuk beriman kepadaNya dalam hidup harian mereka. Oleh karena itu, para remaja-melalui berbagai kelompok yang ada di paroki-perlu dilatih dan dibiasakan untuk mempersiapkan diri berjumpa dengan Sang Sabda yang hadir dalam Kitab Suci yang dibacakan. Mereka perlu diajak membaca teks Kitab Suci yang akan dibacakan pada perayaan Ekaristi hari Minggu, merefleksikannya, bermeditasi dan berkontemplasi dari Sabda tersebut.

Di sini peran para pembawa homili juga sangat menentukan. Melalui homili, mereka menjelaskan Sabda Allah, mewartakan karya penebusan dan penyelamatan Allah dalam hidup para remaja sehingga Sabda Allah yang mereka dengarkan dapat menyegarkan, meneguhkan, menguatkan, menghibur, menyemangati, menuntun, membimbing, mengarahkan, mendorong, sekaligus menegur, mengkritik, menampar dan menantang mereka untuk memberikan diri mereka dan hidup seturut kehendak Allah. Dengan kata lain, pewartaan Sabda dan penjelasannya dalam homili memberi pencerahan, inspirasi, aspirasi, dan motivasi bagi para remaja untuk mengembangkan dan mengaktualisasi diri serta membaktikan kepada Tuhan, Gereja, dan sesama.

“... besarlah daya dan kekuatan Sabda Allah sehingga ... bagi putera-puteri Gereja menjadi kekuatan iman, santapan jiwa, sumber jernih dan kekal hidup rohani. ... "Memang Sabda Allah penuh kehidupan dan kekuatan" (Ibr 4:12) "yang berkuasa membangun dan mengurniakan warisan di antara semua para kudus" (Kis 20:32; lih. 1 Tes 2:13) [DV21].

Firman-Mu itu pelita bagi kakiku dan terang bagi jalanku (Mzr 119:105)

Apabila aku bertemu dengan perkataan-perkataan$\mathrm{Mu}$, maka aku menikmatinya; firman-Mu itu menjadi kegirangan bagiku, dan menjadi kesukaan hatiku. (Yer 15:16)

Jawab Simon Petrus kepada-Nya: "Tuhan, kepada siapakah kami akan pergi? Perkataan-Mu adalah perkataan hidup yang kekal; dan kami telah percaya 
dan tahu, bahwa Engkau adalah Yang Kudus dari Allah." (Yoh 6: 68-69).

Bacaan-bacaan Kitab Suci yang diwartakan dalam Liturgi Sabda pada hari Minggu, tidak jarang juga menampilkan tokoh-tokoh muda sehingga dapat digunakan oleh para penyampai homili untuk secara khusus menyapa kaum remaja dalam homili yang disampaikannya. Berikut beberapa contoh perikop-perikop Kitab Suci yang dimaksud:

\begin{tabular}{|c|c|c|}
\hline Bab \& Ayat & Judul Perikop & Hari Minggu \\
\hline Kel 3: 1-8a. 13-15 & Musa diutus Tuhan & Minggu Prapaskah III/C \\
\hline Kel 20:1-17 & Kesepuluh Firman & Minggu Prapaskah III/B \\
\hline Ul 6:2-6 & Kasih kepada Allah & Minggu Biasa XXXI/B \\
\hline Ul $11: 18.26-28.32$ & Berkat atau Kutuk & Minggu Biasa IX/A \\
\hline Yos 24:1-2a.15-17.18 & $\begin{array}{l}\text { Pembaharuan Janji di } \\
\text { Sikhem }\end{array}$ & Minggu Biasa XXI/B \\
\hline 1 Sam 3:3b-10.19 & Samuel Dipanggil & Minggu Biasa II/B \\
\hline $\begin{array}{l}\text { 1 Sam 16:1b.6 } \\
13.22-23\end{array}$ & Daud Diurapi Menjadi Raja & Minggu Prapaskah IV/A \\
\hline 1 Raj 3:5.7-12 & $\begin{array}{l}\text { Doa Salomo Memohon } \\
\text { Hikmat }\end{array}$ & Minggu Biasa XVII/A \\
\hline 1 Raj 17:17-24 & $\begin{array}{l}\text { Elia Membangkitkan Anak } \\
\text { Janda dari Sarfat }\end{array}$ & Minggu Biasa X/C \\
\hline 2 Mak $7: 1-2.9-14$ & $\begin{array}{l}\text { Tujuh Orang Bersaudara } \\
\text { serta Ibunya Disengsarakan }\end{array}$ & Minggu Biasa XXXII/C \\
\hline Yes 6:1-2. 3-8 & $\begin{array}{l}\text { Yesaya Mendapat } \\
\text { Panggilan Allah }\end{array}$ & Minggu Biasa V/C \\
\hline Yer 1: 4-5. 17-19 & $\begin{array}{l}\text { Yeremia Dipanggil Allah } \\
\text { dan Diutus }\end{array}$ & Minggu Biasa IV/C \\
\hline $\begin{array}{l}\text { Mat 4:12-23 } \\
\text { Mark 1:4-20 } \\
\text { Luk 5:1-5 }\end{array}$ & $\begin{array}{l}\text { Memanggil Murid-Murid } \\
\text { yang Pertama }\end{array}$ & $\begin{array}{l}\text { Minggu Biasa III/A } \\
\text { Minggu Biasa III/B } \\
\text { Minggu Biasa V/C }\end{array}$ \\
\hline Mark 10:17-27 & $\begin{array}{l}\text { Orang Kaya Sukar Masuk } \\
\text { Kerajaan Allah }\end{array}$ & Minggu Biasa XXVIII/B \\
\hline Mat 21:28-32 & $\begin{array}{l}\text { Perumpamaan tentang Dua } \\
\text { Orang Anak }\end{array}$ & Minggu Biasa XXVI/A \\
\hline
\end{tabular}

Liturgi Sabda diakhiri dengan pengakuan iman dan doa umat. Dengan pengantar singkat, pemimpin upacara dapat mengajak umat beriman, khususnya kaum muda untuk membaharui pengakuan iman, 
komitmen dan janji baptisnya yang pernah dinyatakannya dahulu dalam pembaptisan. Kalau dahulu mereka diwakili oleh orangtua mereka maka sekarang mereka harus mengucapkannya sendiri. Dalam Doa Umat, kaum muda dapat diajak untuk mengungkapkan harapan, permohonan, dan dambaan hati mereka kepada Allah yang mengasihi dan menerima mereka apa adanya.

Berbagai kegiatan yang dapat dilaksanakan untuk mempersiapkan para remaja sehingga dapat mendukung tahap pencerahan ini adalah sharing Kitab Suci, melatih diri membangun keheningan, latihan meditasi terpimpin, atau retret yang berfokus pada relasi dengan Allah. Sharing Kitab Suci dapat dilaksanakan dalam kelompok dimana setiap anggota kelompok sudah kenal satu dengan yang lain. Mereka mendengarkan Sabda Allah secara bersama serta menghayatiNya dalam kehidupan konkrit sehari-hari melalui sikap penghargaan terhadap keheningan, matiraga dan disiplin hidup. Melalui keheningan ini mereka akan sangat terbantu untuk menciptakan ruang dan waktu untuk perjumpaan pribadi dengan Tuhan. Latihan meditasi terpimpin seperti latihan pernafasan bisa menjadi tahap awal untuk meditasi, kontemplasi dan fantasi. Refleksi atas suatu kisah Injil dapat membantu juga. Retret yang berfokus pada pengembangan relasi personal dengan Yesus dapat menciptakan waktu dan kesempatan khusus bagi para remaja untuk melakukan meditasi terpimpin, sharing Kitab Suci, doa hening, doa bersama, menerima sakramen Tobat dan sakramen Ekaristi dalam rangka pengembangan dan pendalaman relasi personal dengan Yesus.

Liturgi Ekaristi yang memuncak dalam Komuni Kudus merupakan tahap persatuan. Persatuan dengan Kristus dan GerejaNya sudah dimulai saat persiapan persembahan, meningkat dalam dialog pembuka prefasi: "marilah mengarahkan hati kepada Tuhan" - "sudah kami arahkan" serta "marilah bersyukur kepada Tuhan" - "sudah layak dan sepantasnya", selanjutnya persatuan dengan Kristus dan GerejaNya diungkapkan secara lebih mendalam di dalam Doa Syukur Agung yang ditutup dengan doksologi. Doa Bapa Kami mengarahkan peserta Misa untuk mengalami secara nyata persatuan dengan sesamanya: "berilah kami rejeki pada hari ini dan ampunilah kami seperti kami pun mengampuni yang bersalah kepada kami." Doa dan salam damai menegaskan persatuan dengan sesama dalam Tuhan. Kemudian dalam Komuni Kudus, persatuan tersebut mencapai puncaknya, yakni para peserta Ekaristi 
dipersatukan dengan Kristus, GerejaNya dan sesamanya:

Barangsiapa makan daging-Ku dan minum darah- $\mathrm{Ku}$, ia tinggal di dalam Aku dan Aku di dalam dia. Sama seperti Bapa yang hidup mengutus Aku dan Aku hidup oleh Bapa, demikian juga barangsiapa yang memakan Aku, akan hidup oleh Aku (Yoh 6:56-57).

Persatuan dengan Kristus dan GerejaNya menjadikan mereka semakin hari semakin bertumbuh menjadi sehati-sejiwasepikir-serasa - senasib dengan Yesus dan GerejaNya sehingga mereka pun memiliki daya kekuatan untuk berbagi dengan sesamanya serta melaksanakan perutusan Gereja di tengah masyarakatnya. Vazhakala (2005) mengatakan bahwa persatuan dengan Kristus dalam Ekaristi Kudus mendatangkan energi, kekuatan, vitalitas, dan semangat bagi beata Teresa dari Kalkuta untuk melanjutkan karya-karya pelayanannya. Lebih lanjut Vazhakala menuturkan:

"Bukan dia (beata Teresa) yang hidup, melainkan Kristuslah yang hidup di dalam dirinya dan bekerja melalui dia. Ia mampu melaǩkukan semua hal di dalam Yesus, bagi Yesus, dan dengan Yesus yang menguatkan dia melalui penerimaan Komuni Kudus setiap hari."

Dengan demikian, persatuan dengan Kristus dan GerejaNya dalam perayaan Ekaristi semakin menegaskan komitmen para remaja untuk menjadi utusan dan saksi Kristus, menumbuhkan rasa empati dan solidaritas dengan kaum miskin dan menderita seperti Kristus lakukan. Kesatuan dengan Kristus juga membuat mereka memiliki keberanian untuk membantu orang lain yang membutuhkan dan bersedia berbagi rahmat dan berkat dengan sesamanya.

Berbagai kegiatan yang dapat membantu mengasah kaum muda terkait dengan hal ini adalah live in, berbagai bentuk kunjungan sosial ke orang-orang lanjut usia, orang-orang yang mengalami keterbeläkangan mental atau berkebutuhan kliusus. Rekoleksi atau retret atau seminar dengan topik-topik perdamaian, diskriminasi, keadilan, kemiskinan, isu-isu sosial atau isu-isu moral, dsb.

\section{Kesimpulan dan Saran}

Kaum remaja adalah pribadi yang sedang mencari dan berusaha menemukan identitas dirinya sendiri. Mereka secara dinamis mengupayakan pertumbuhan dan perkembangan diri mereka 
secara khas. Perkembangan hidup rohani remaja mencakup tiga tahap yang terkait erat dan tak terpisahkan, yakni: tahap pemurnian, tahap pencerahan, dan tahap persatuan. Ketiga tahap perkembangan hidup rohani tersebut juga ditemukan di dalam perayaan Ekaristi, yakni: tahap pemurnian - ritus pertobatan, tahap pencerahan - Liturgi Sabda, dan tahap persatuan - Liturgi Ekaristi yang memuncak dalam Komuni Kudus.

Perayaan Ekaristi hari Minggu di paroki-paroki pada umumnya masih secara rutin dan teratur diikuti oleh para remaja entah apapun motivasi dasar mereka. Kemauan mereka untuk hadir dalam Perayaan Ekaristi hari Minggu harus dipandang secara positif. Karena itu, tantangan besar yang ada dihadapan para petugas pastoral, khususnya para imam pemimpin Misa adalah bagaimana menjadikan perayaan Ekaristi hari Minggu sebagai peluang atau kesempatan emas bagi Gereja untuk membantu pertumbuhan dan perkembangan hidup rohani remaja saat ini.

Untuk menjawabi tantangan tersebut, maka para petugas pastoral, khususnya para imam, ditantang mempersiapkan Perayaan Ekaristi dengan baik dan serius, mengembangkan kreatifitasnya, dan memanfaatkan berbagai kemungkinan penyesuaian yang dapat dilakukan dalam perayaan Ekaristi. Contoh sederhana yang bisa dilakukan: menyapa kaum muda secara khusus dalam pengantar, homili, kata penutup sebelum perutusan, dsb. Pendampingan secara teratur dan serius bagi kelompok-kelompok remaja yang terlibat dalam berbagai bentuk pelayanan dalam perayaan Ekaristi hari Minggu dan memberi peran-peran baru bagi mereka. Mempersiapkan homili sebaik mungkin dan memberi porsi yang cukup untuk menyapa dan menantang para remaja sehingga mereka mendapatkan inspirasi, motivasi, dan keyakinan untuk tetap berkomitmen kepada Yesus dan melaksanakan pemuridan dalam hidup harian. Selain itu dibutuhkan kerjasama dengan para Pembina kaum remaja sehingga kegiatan dan pertemuan para remaja juga mempersiapkan dan mengarah kepada perayaan Ekaristi hari Minggu dan sebaliknya. 


\section{Daftar Pustaka}

Mayor. 1999. Tinjauan Pelaksanaan Katekese Perayaan Ekaristi. Karya Tidak Diterbitkan.

Mazzella, Robert S. (Tanpa Tanggal). Spiritual Exercises dalam The Catholic Encyclopedia for School and Home (volume 10). Him. 317-318.

Moore, Joseph. Winter 1988. Adolescent Spiritual Development: Stages and Strategies dalam Religious Education, Vol. 83, No.1.

Roguet, A. M. 1984. Misa Kudus: Menyelami Rahasianya. Ende: Nusa Indah.

Tangdilintin, Philips. 2008. Pembinaan Generasi Muda dengan Proses Manajerial VOSRAM. Yogyakarta: Kanisius.

Vazhakala, Sebastian. 2005. The Holy Eucharist in the Life of Blessed Teresa of Calcutta dalam http://www.ewtn.com/ library/MARY/HETERCAL.HTMdiunduh 15 Oktober 2011. 


\section{PERSYARATAN PENULISAN ILMIAH DI JURNAL JPAK WIDYA YUWANA MADIUN}

01. Jumal IImiah JPAK Widya Yuwana memuat hasil-hasil Penelitian, Hasil Refleksi, atau Hasil Kajian Kritis tentang Pendidikan Agama Katolik yang belum pernah dimuat atau dipublikasikan di Majalah/Jurnal IImiah lainnya.

02. Artikel ditulis dalam Bahasa Indonesia atau Inggris sepanjang 7500-10.000 kata dilengkapi dengan Ábstrak sepanjang 50-70 kata dan 3-5 kata kunci.

03. Artikel Hasil Refleksi atau Kajian Kritis memuat: Judul Tulisan, Nama Penulis, Instansi tempat bernaung Penulis, Abstrak (Indonesia/Inggris), Kata-kata Kunci, Pendahuluan (tanpa anak judul), Isi (subjudul-subjudul sesuai kebutuhan), Penutup (kesimpulan dan saran), Daftar Pustaka.

04. Artikel Hasil Penelitian memuat: Judul Penelitian, Nama Penulis, Instansi tempat bernaung Penulis, Abstrak (Indonesia/lnggris), Kata-kata Kunci, Latar Belakang Penelitian, Tinjauan Pustaka, Metode Penelitian, Hasil Penelitian, Penutup (kesimpulan dan saran), Daftar Pustaka

05. Catatan-catatan berupa referensi disajikan dalam model catatan lambung.

Contoh: Menurut Caputo, makna religius kehidupan harus berpangkal pada pergulatan diri yang terus menerus dengan ketidakpastian yang radikal yang disuguhkan oleh masa depan absolut (Caputo, 2001: 15)

06. Kutipan lebih dari empat baris diketik dengan spasi tunggal dan diberi baris baru.

Contoh: Religions claim that they know man an the world as these really are, yet they they differ in their views of reality. Question therefore arises as to how the claims to truth by various religions are related. Are they complementary? Do they contradict or overlap one another? What -according to the religious traditions themselves-is the nature of religious knowledge? (Vroom, 1989: 13)

07. Kutipan kurang dari empat baris ditulis sebagai sambungan kalimat dan dimasukkan dalam teks dengan memakai tanda petik.

Contoh: Dalam kedalaman mistiknya, Agustinus pernah mengatakan "saya tidak tahu apakah yang saya percayai itu adalah Tuhan atau bukan." (Agustinus, 1997: 195)

08. Daftar Pustaka diurutkan secara alfabetis dan hanya memuat literature yang dirujuk dalam artikel. Contoh;

Tylor, E. B., 1903. Primitive Culture: Researches Into the Development of Mythology,

Philosophy, Religion, Language, Ert, and Custom, John Murray: London

Aswinarno, Hardi, 2008. "Theology of Liberation As a Constitute of Consciousness," dalam Jurnal RELIGIONo. I, April 2008, hal. 25-35.

Borgelt, C., 2003. Finding Association Rules with the Apriori Algorthm, http:/hwww.fuzzi.cs.uni-magdeburg.de/-borgelt/aprioril. Juni 20, 2007

Derivaties Research Unicorporated. http//fbox.vt.edu.10021/business/finance/ dmc/RU/content.html.Accesed May 13, 2003 